Babeş-Bolyai

University

Cluj-Napoca

TRANSYLVANIAN REVIEW

OF ADMINISTRATIVE SCIENCES

8) Edited by Department of Public Administration and Management Faculty of Political, Administrative and Communication Sciences 


\title{
Transylvanian Review of Administrative Sciences
}

\author{
№.62 臣/ February // 2027
}

Senior Editor: Călin Emilian Hinţea

Director: Ciprian Tripon

Editor: Cristina Hințea

Administrative director: Ovidiu Boldor

Editorial Board: Raluca Antonie, Marton Balogh, Natalia Balogh, Daniel Buda, Simona Creța, Marius Dodu, Dacian Dragoş, Călin Ghiolţan, Cristina Haruţa, Adrian Hudrea, Dan Lazăr, Cornelia Macarie, Bogdan Moldovan, Octavian Moldovan, Bogdana Neamţu, Alexandru Pavel, Horia Raboca, Bianca Radu, Liviu Radu, Ana Elena Ranta, Viorel Stănică, Raluca Suciu, Tudor Ţiclău, Nicu Urs

\section{INTERNATIONAL ADVISORY BOARD}

Carole NEVES, Smithsonian Institute, Washington, DC

Allan ROSENBAUM, Florida International University

Arno LOESSNER, University of Delaware

Roger HAMLIN, Michigan State University

Laszlo VARADI, Corvinus University of Budapest

Eric STRAUSS, Michigan State University

Gyorgy JENEl, Corvinus University of Budapest

Adriano GIOVANNELLI, Genoa University

Bernadine Van GRAMBERG, Victoria University

Julian TEICHER, Monash University

Geert BOUCKAERT, Catholic University of Leuven

Veronica JUNJAN, University of Twente

György HAJNAL, Corvinus University of Budapest

Taco BRANDSEN, Radboud University Nijmegen, Secretary-General of the European Association for Public Administration Accreditation (EAPAA)

Juraj NEMEC, Masaryk University, president of The Network of Institutes and Schools of Public Administration in Central and Eastern Europe (Nispacee)

Patrizia MAGARÒ, Genoa University

Maria ARISTIGUETA, University of Delaware

Yüksel DEMIRKAYA, Marmara University

Marian PREDA, University of Bucharest

Marius PROFIROIU, Bucharest Academy of Economic Studies

Alexander HENDERSON, Long Island University

Gregory PORUMBESCU, Northern Illinois University 
Transylvanian Review of Administrative Sciences has been selected for coverage in Thomson Reuters products and custom information services. Beginning with no. $22 \mathrm{E} / 2008$, this publication is indexed and abstracted in the following:

1. Social Sciences Citation index ${ }^{\circledR}$

2. Social Scisearch ${ }^{\circledR}$

3. Journal Citation Report/Social Sciences Edition

Transylvanian Review of Administrative Sciences is also listed in EBSCO, IBSS - International Bibliography of Social Sciences, Elsevier Bibliographic Databases, PA@BABEL Public Administration's dataBase for Accessing academic publications in European Languages and DOAJ - Directory of open access journals. 


\section{CONTENTS}

\section{Delia Cristina BALABAN}

Viviana HUȚULEAC

5 Public Measures to Deal with the Negative Effects of Intra-EU Migration.

Case Study: Suceava County, Romania

Mehtap ÇAKMAK BARSBAY

Mustafa Kemal ÖKTEM

22 The Competency Movement in Public Hospitals:

Analysing the Competencies of Hospital Executive Managers

Andrei CHIRCĂ

Dan Tudor LAZĂR

44 Cluj-Napoca without Students:

An Estimation of the Gap in the City's Economy

György HAJNAL

Iga JEZIORSKA

60 Collaborative Governance Regimes in Illiberal Democracies:

A Comparative Case of Drug Harm Reduction Policy in Central-Eastern Europe

Zhang HUA

Liu YANING

Jilong WANG

81 Study of the Transformation of Industrial Heritage

from the Perspective of Holistic Governance

\section{Dejan ILIEV}

94 Urban Regeneration and Changes Driven by Tourism and the 'Skopje 2014' Project

Juraj NEMEC

Matúš KUBÁK

Gleb DONIN

Zuzana KOTHEROVÁ

115 Efficiency of Public Procurement in the Czech and Slovak Health Care Sectors 
Marius Constantin PROFIROIU

Maria-Roxana BRIȘCARIU

134 Universities as 'Drivers' of Local and Regional Development

Cristina ȘERBĂNICĂ

153 Territorial Innovation Patterns in Romania.

Future Pathways for Smart Specialization 
DOI: $10.24193 /$ tras.62E.6

Published First Online: 02/25/2021

\section{URBAN REGENERATION}

\section{AND CHANGES DRIVEN BY TOURISM \\ AND THE 'SKOPJE 2014' PROJECT}

\section{Dejan ILIEV}

\section{Dejan ILIEV}

Associate professor, Faculty of Natural Sciences

and Mathematics, Institute of Geography,

Ss. Cyril and Methodius University, Skopje, North Macedonia

Tel.: 00389-2-324.9703

E-mail: diliev@pmf.ukim.mk

\section{Abstract}

The current paper explores the relationship between urban regeneration, tourism and culture, and offers a common approach that each of these three concepts can bring. The paper proposes and develops a new and integrated conceptual analytical framework. The analysis uses the example of the capital Skopje, which provides a suitable framework for interpreting the process. The study uses combined research methods and analysis to obtain a critical synthesis. Skopje has catalyzed a new example of urban regeneration driven by tourism and the 'Skopje 2014' project. The results show that, except for the old city's core, which was generally refurbished with the 'Skopje 2014' project, new tourist values were also promoted in other peripheral municipalities of the city. The number, spatial concentration and nationality of foreign tourists have changed in the analyzed period. As well, the findings indicate changes in the geography and business of hotels/accommodation establishments and their increasing use in recent years. This study fits into the theoretical debate on the determinants of tourism/culture-led urban regeneration and provides appropriate theoretical contributions to literature, as well as a set of recommendations that can be useful for public sector authorities and policymakers.

Keywords: urban regeneration, tourism, culture, place, transformation, Skopje. 


\section{Introduction}

Many researchers highlight the close relationship between tourism and urban regeneration (Coles, 2003; Couch and Farr, 2000; Karski, 1990; Law, 1991, 1992, 2000; Martin and Mason, 1988; Stevenson, 2013; Swarbrooke, 2000), as well as culture and urban regeneration (Evans, 2004; Miles and Paddison, 2005; Sasaki, 2010). Consequently, the current study intends to encourage the debate on the role of tourism and culture in urban regeneration processes. To open a wide theoretical debate, the following questions will be considered: Can tourism contribute to the process of urban regeneration? (Karski, 1990; Law, 1991, 1992). Can tourism development favor the path of city regeneration through new trajectories based on its cultural, creative and tourism resources? (Couch and Farr, 2000; Evans, 2003, 2004, 2005; Maitland, 2007a, 2007b; Richards, 2014; Richards and Wilson, 2007). What can this current study add to contemporary debates and how this case study might help us understand the role of tourism and cultural projects within an urban regeneration context? Although many international scholars acknowledge the importance of tourism and culture in urban regeneration, Skopje's research from this perspective is still limited. Previous relevant papers focus on topics related to the different ways in shaping Skopje's variegated urban landscapes (Bouzarovski, 2011), sustainable urban development in Skopje (Donevska, 2017), the creation of a nationalistic planning doctrine through the 'Skopje 2014' (Grcheva, 2019), different forms of heritage in Skopje (Dimova, 2019), and they do not pay attention to the role of tourism and culture in the process of urban regeneration. Therefore, the current study aims to complement this research gap in the literature, and offers a better understanding of the complexity of this process.

This paper aims to provide some theoretical knowledge about the role of tourism and culture in urban regeneration, and to develop a conceptual framework that represents how contemporary tourism activities and culture projects affect urban regeneration. Thus, the paper designs an integrated conceptual framework, which combines the drivers of tourism-led urban regeneration (Law, 2000; Swarbrooke, 2000), the theoretical constructs connected to the regeneration of the city (Karski, 1990; Law, 1991, 1992, 2000; Martin and Mason, 1988), and the factors that encourage revitalization and promotion of the new place in old space in the city (Joksimovic et al., 2014; Rátz, Smith and Michalkó, 2008). The framework is applied to the capital Skopje. This city was chosen because it is associated with various projects that, beginning from the renewal of the old city core, are shifting the city image in diverse ways, revitalizing the urban space.

The paper is organized into six sections. The second section reviews the literature and the main concepts used in the research. The third section describes the methodology used to develop the case study. The fourth section presents the case of Skopje. The fifth section summarizes the study and discusses the implications of the study findings. The sixth section stresses the limitations of the study and proposes a series of critical issues for future research. 


\section{Literature review}

A theoretical grounding is necessary to situate how we understand the concept of tourism-led urban regeneration (see Law, 1991, 1992, 1993, 1996, 2000, 2002; Martin and Mason, 1988; Swarbrooke, 2000). Martin and Mason (1988) noted that 'one of the attractions of using tourism as an element in urban regeneration lies in the economic justification that it can provide for the physical refurbishing and renewal of decayed urban centers' (p. 77). Later, Law (2000), in his theoretical model of tourism and urban regeneration, offers a better understanding of the physical, economic and social regeneration of the city. He explains that regeneration can be achieved through increased visitor numbers, creation of a new image, increased income, expansion of other economic activities, population growth, enhanced civic pride, job creation, and further investment in attractions and environmental improvements. However, the disadvantage of this model is that it does not include the physical renewal of the city core through culture-led regeneration.

The motivations for urban regeneration are heterogeneous. Smith (2007) demonstrated that they may form part of a government's plan for economic or cultural regeneration; as a means of attracting investment and developing tourism; or initiating environmental improvements and infrastructure developments. Smith (2007) says that 'the common characteristic of both the tourism development and the regeneration process is that they seek to transform old spaces whilst recreating new ones' (p. 9), therefore, tourism development can be considered as an engine for urban regeneration (Galdini, 2007).

Law (2000) noted that 'tourism and tourism resources are not confined to the city center. There are often significant visitor attractions in the outer areas and the task here is to link them with those in the city center, particularly with regard to transport' (pp. 128-129). There is broad debate about the role of tourism in generating new opportunities for new spaces in urban zones (Coles, 2003; Law, 2000; Joksimović et al., 2014; Puczko, Ratz and Smith, 2007; Rátz et al., 2008). Belgrade and Budapest were demonstrated as new examples of urban regeneration driven by tourism (see Joksimović et al., 2014; Rátz et al., 2008), where it was presented that the tradition$\mathrm{al}$, new and regenerated tourist values are intended to mark and symbolize broader change and regeneration of the peripheral urban municipalities of the city.

There is also debate in the literature about the role of tourist visitors in the city's regeneration. According to Maitland (2007b) exploring these issues means gaining a better understanding of what kind of visitor moves beyond traditional tourist beats and what draws them to new zones of the city. Some authors consider that 'these visitors may be drawn away from more familiar tourist attractions (Maitland and Newman, 2004) to new 'cultural clusters' (Mommaas, 2004) or new areas of gentrification that offer the restaurants and other amenities demanded by young professionals. 'They will contribute to the process of gentrification and regeneration' (quoted in Maitland, 2007b, pp. 31-32). The localities and buildings must be reconfigured to attract visitors or, as Norris (2003) noted: if we build it, they will come! 
The geography of hotels and other accommodation facilities also plays an important role in the regeneration of the city. Several models have been proposed in the literature that explains the intra-urban location of hotels. The Ritter and Ashworth models attracted the most attention. Ritter (1986) provided a model of urban hotel distribution determined by the development of transportation technology. Initially, hotels occupied central locations, and later started to disperse from the inner city toward the periphery zones. Later, Ashworth (1989) proposed the theoretical THC (Tourist Historic City) model, with six types of urban hotel locations. The availability of tourist attractions and transportation services are highlighted as the most important factors affecting the location and distribution of the hotels. Generally, the spatial distribution of hotels and/or accommodation establishments is a dynamic process that affects urban regeneration and the urban landscape.

Culture is also an important factor in urban regeneration (see Evans, 2004; Miles and Paddison, 2005; Sasaki, 2010). Evans (2004) has identified three models through which cultural activity is incorporated into the regeneration process: (1) culture-led regeneration, where cultural activity is seen as the catalyst and engine of regeneration; (2) cultural regeneration, where cultural activity is fully integrated into strategic planning along with other activities in the environmental, social and economic spheres; (3) culture and regeneration, where cultural activity is not fully integrated at the strategic development planning stage. Evans (2005) noted that activity associated with culture-led regeneration could be the design and construction or reusing of a building. Richards and Wilson (2007) point out that 'the regeneration process seems to require a mix of physical icons and spaces that can make the creative process more visible and tangible' (p. 23). Cultural regeneration plays an important role in transforming old spaces into new ones in the city (Rátz et al., 2008). In general, scholars have introduced different concepts and approaches to culture-led regeneration in cities, and the fact is that such activities can contribute to raising the profile of the city, its branding and re-branding.

Based on the previous literature review, the analytical conceptual framework is depicted in Figure 2.

\section{Methodology}

\subsection{Research area}

The paper explores the case of the City of Skopje. According to the nomenclature of territorial statistical units (NUTS 3), the Skopje Region is one of the eight statistical regions in North Macedonia. This region is the smallest and covers only $7.3 \%$ of the total land area of the country, but according to the data for 2017, it is the most populated region with 622,750 inhabitants (estimated population) or $30.2 \%$ of the total population, and the most densely populated region with 345.3 inhabitants per $\mathrm{km}^{2}$ (State Statistical Office of the Republic of Macedonia [SSORM], 2018).

The Skopje Region is divided into 17 municipalities. The municipalities Centar, Karposh, Kisela Voda, Aerodrom, Gazi Baba, Butel, Chair, Gjorche Petrov, Saraj and 
Shuto Orizari consist the City of Skopje. Thus, the current study is limited to the 10 municipalities that cover the urban area of the City of Skopje (Figure 1).

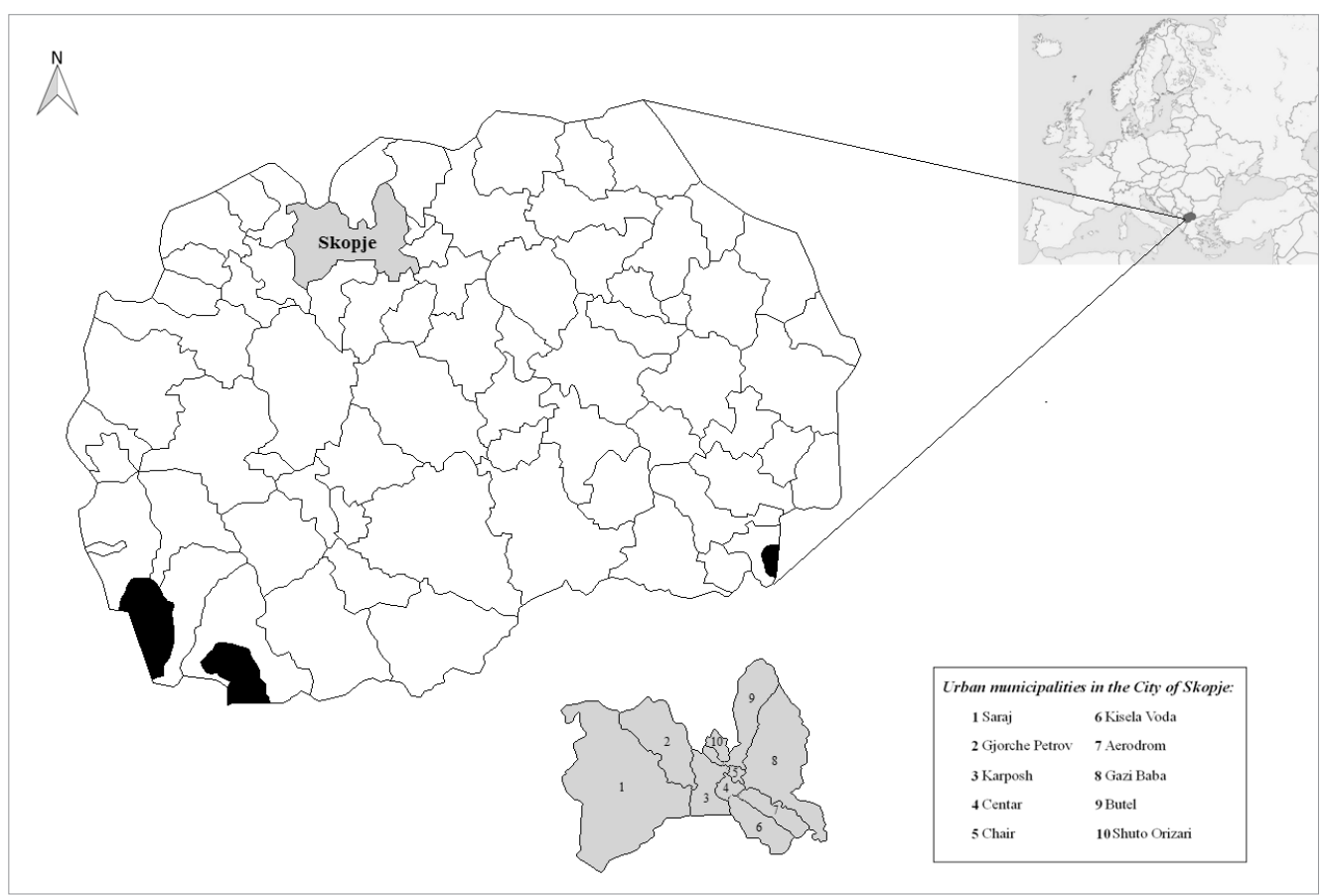

Figure 1: Geographic location of Skopje

Source: Author

\subsection{Research design}

This paper has three main goals: to contribute to the theoretical debate on the role of tourism and culture in the processes of urban regeneration; to develop an integrated conceptual analytical framework; and to apply this framework to the case of Skopje. The conceptual framework is constructed in Figure 2.

The framework proposes that there is a relationship between tourism development and urban regeneration; there is a relationship between culture-led regeneration, tourism development and urban regeneration; there is a relationship between the spatial distribution of tourist values, tourism development and urban regeneration; there is a relationship between restoring foreign tourist flows, tourism development and urban regeneration; and there is a relationship between redistribution of the hotel business and accommodation establishments, tourism development and urban regeneration. The conceptual framework has been applied to Skopje, which is assumed to have catalyzed a new example of urban regeneration driven by tourism and the 'Skopje 2014' project. The assumption is that the city has been able to transform its structure to innovate and develop new trajectories. 


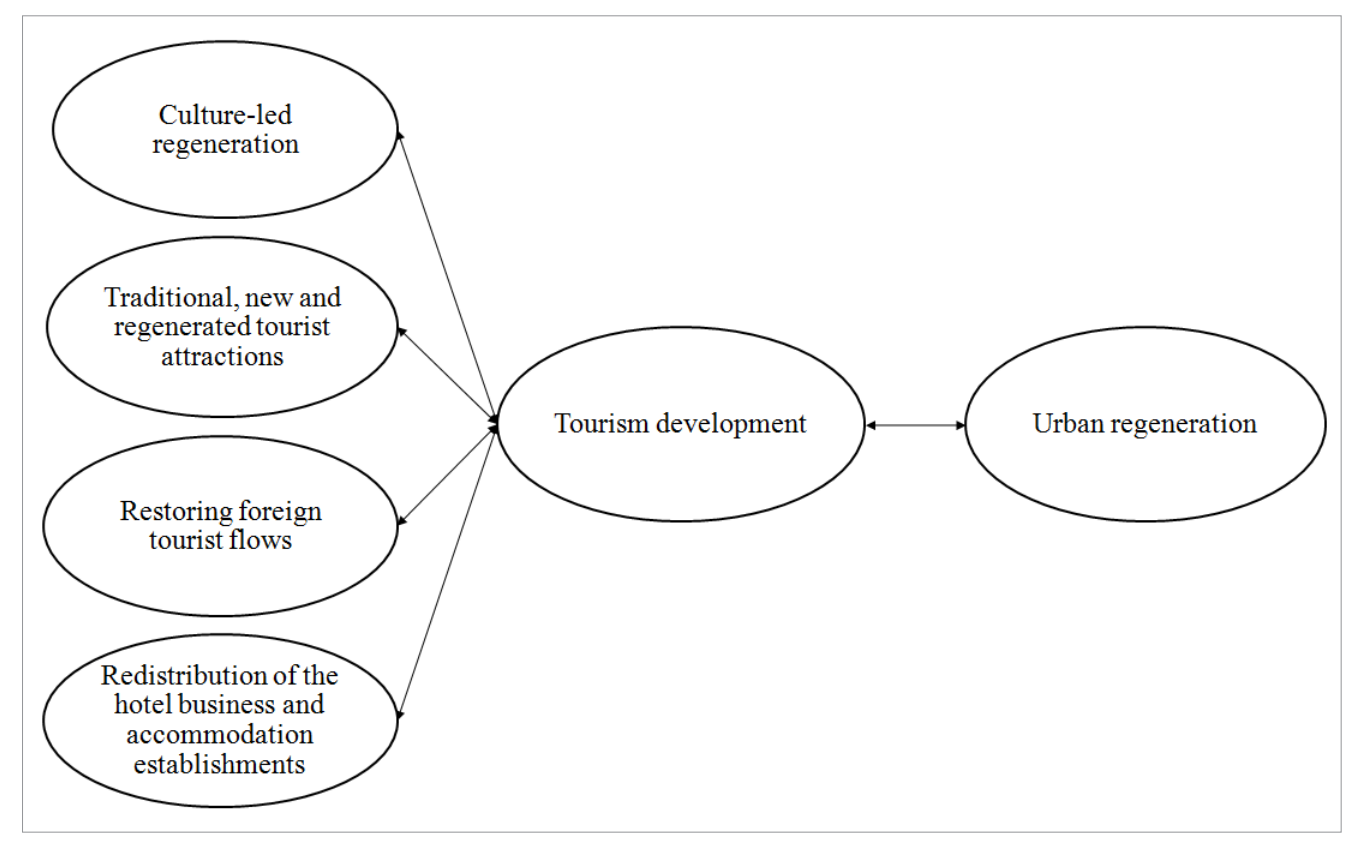

Figure 2: Conceptual framework linking culture, tourism and urban regeneration

Source: Author

Primary and secondary data are used in the analysis. Primary data are the result of the author's fieldwork and include an inventory of new tourist attractions, determining their location, years of construction and regeneration of existing tourist attractions. Data related to traditional attractions were taken from tourism strategies and spatial plans. Three criteria are used in the classification of tourist attractions: (1) the historical value of the object; (2) new development/new value; and (3) whether the objects/buildings were part of the regeneration process. Consequently, three types of values are classified: traditional, new and regenerated tourist attractions.

The secondary data were derived from the State Statistical Office, Eurostat, the 'Tourism Strategy with Action Plan of the City of Skopje for the period 2014-2018', the 'Spatial Plan of the Skopje Region 2005-2020', reviews of relevant literature and websites.

ArcGIS and statistical methods are used for data processing and presentation of results. GIS as a tool is used in tourism research (see Dye and Shaw, 2007), especially for mapping the distribution of tourists and movement models (Chancellor and Cole, 2008; Lau and McKercher, 2006; Yang and Wong, 2013), and for the spatial diffusion of accommodation capacities (Sarrión-Gavilán, Benítez-Márquez and Mora-Rangel, 2015). In the current research, the GIS tool is used to present the geography of the tourist attractions, as well as to present the changes in the geography and the use of the accommodation capacities. GIS mapping is important because it complements the analysis of the results in the case study. 
Secondary data collected in the initial stage of the research were analyzed by two statistical methods. First, the index of the effectiveness of foreign tourists (Ef) was applied (Joksimović et al., 2014):

$$
\mathrm{Ef}=\frac{\sqrt{\mathrm{AOs} \cdot \mathrm{PPs}} \cdot \sqrt{\mathrm{FTn}}}{3}
$$

where, AOs is an average number of overnights stays by foreign tourists from a specific country, PPs is the year 2016 purchasing power parity of the country from which tourists came, FTn is the number of foreign tourists in the same year.

Second, the bed occupancy (as a percentage) is calculated using the following equation:

$$
\text { Bed occupancy rate }(\%)=\frac{\text { number of foreign overnight stays }}{\text { total number of beds } \times 365} \times 100
$$

Using the Bo method ${ }^{1}$, the aim is to present the changes that have occurred in the hotel/accommodation business and the utilization of accommodation capacities.

\section{Case study: the capital Skopje}

Skopje is the capital and an important administrative, political, economic, cultural, university and health center in North Macedonia. In recent years, like other metropolises in Southeast Europe, Skopje has ambitions to become a modern tourist city. Skopje is trying to present itself as the main port in Southeast Europe, valorizing the rich historical and cultural heritage from ancient times to modern times, while trying to protect and promote it.

The city center is the oldest part of Skopje. In 2007, the ruling right-wing party declared an erection of cultural monuments and buildings in the city center of Skopje as a major political priority (Bouzarovski, 2011). The intensive investment in the city core that was characterized by post-socialist images has resulted in urban renewal, or as Grcheva (2019) notes, the introducing of a completely new neo-historic architectural style. The main role in the reconstruction of the city center was played by the project 'Skopje 2014'. The core of 'Skopje 2014' is around the main city square and spreads over both sides of the river Vardar as an axis of coordination (Figure 3; Figure 4). With the construction of new cultural monuments and buildings, the 'Skopje 2014' project has triggered a radical transformation of the cultural morphology

1 For businesses like hotels, apartments and other accommodation establishments that have beds available for use, the number of used beds compared to the number of total beds available is calculated using a measurement known as the occupancy rate or Bo method. Bed occupancy rates are considered of utmost importance for the hotel's management, especially for the sales department. Bed occupancy rate that is less than the hotel capacity means that there are lost selling opportunities, which leads to a reduction in hotel revenue and/or profits. Essentially, bed occupancy rate is important because it can indicate the success or failure of hotels and their business activities. 



Figure 3: Old city core (Square Macedonia) - architectural change and new city's image (before and after the 'Skopje 2014' project).

and architecture of the city's core. The project has cost over 667 million euro (Balkan Investigative Reporting Network, 2014; quoted in Grcheva, 2019, p. 151).

The project 'Skopje 2014', as Grcheva (2019) notes, includes more than 100 new buildings, monuments - a mix of historical figures from different eras and facade changes. The most famous are: Porta Macedonia, the monument of Alexander the Great, the monument of Philip II, the monuments of Goce Delchev, Skenderbeg, Tsar Samuel, St. Cyril and Methodius, St. Clement and Naum of Ohrid; museums, memorial rooms and national cultural buildings such as the Archaeological Museum of Macedonia, the Museum of the Macedonian Struggle, the Holocaust Memorial Center for the Jews of Macedonia, the Memorial House of Mother Teresa, etc. Grcheva (2019) says 'all of this resulted in a heavily dense central zone, which is today dominated exclusively by the Skopje 2014 project that hides all remains from previous architectural periods' (p. 150). The main ambition of the project was to strengthen the Macedonian cultural identity and attract international visitors. According to the 'Tourism Strategy with Action Plan of the City of Skopje for the period 2014-2018', the project 'Skopje 2014' aims to enrich the tourist offer of the city, to increase the number of tourists and to improve the city image. Architectural buildings and monuments are the reason for several hours of enjoyment of tourists in the city center. 


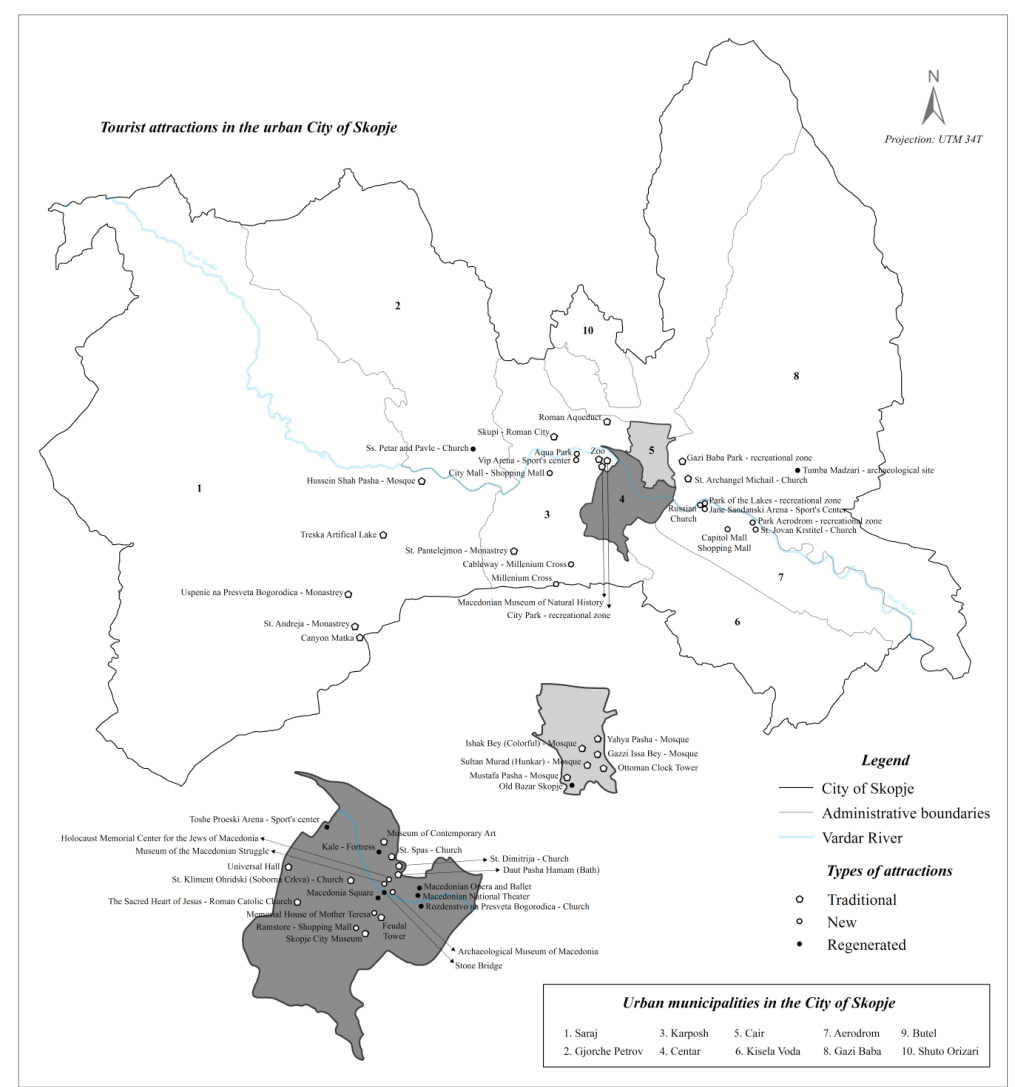

Figure 4: Classification and spatial dispersion of tourist attractions in Skopje (10 urban municipalities)

Source: Author

Galdini (2007) says that 'culture has the potential to bring a regenerative effect on the town's economy and nature' (p. 101). Consequently, the policy of the central government through the 'Skopje 2014' project aimed to renew the City of Skopje and to stimulate economic and tourism development. On the other hand, although the central government claimed that the paradigm of cultural progress in Skopje has changed, the 'Skopje 2014' project remained controversial among citizens with conflicting interests.

Florida (2002) emphasizes that creative cities probably need creative governments and creative leadership. Some authors have noted that 'in the case of tourism, governments are often part of the industry, as owners and operators of infrastructure and attractions and through organizations such as tourism boards and convention and visitors' bureaux' (Edwards, Griffin and Hayllar, 2008, p. 1038). Central and local authorities have encouraged the development of tourism in Skopje. As well, the general trends in society stimulated the investment and expansion of tourist and service capacities. Outside the city center, new tourist attractions, like for example, recreational zones, shopping malls, sports centers, Aqua Park, cableway and other 
facilities were also built (Figure 4). As a consequence, tourist movements dispersed to other urban municipalities.

Through the development of tourism, the advancement and vitalization of the spatial contents in the city are provided (Ministry of Environment and Physical Planning [MEPP], 2010). Tourism and catering businesses have expanded in Skopje. The number of shops, restaurants, taverns, themed restaurants, coffee bars and other service activities has increased in the city. New modern shopping malls have been built in the municipalities of Centar, Karposh and Aerodrom, which have encouraged the development of shopping tourism. According to the 'Tourism Strategy with Action Plan of the City of Skopje for the period 2014-2018', the City of Skopje was transformed, most of the planned projects were implemented, and some of them are in the final stage of realization. For example, the projects for construction of a cable car to Vodno Mountain and modernization of the public transport were realized, while the following projects are in the final stage of realization: construction of a new and renovation of the old road infrastructure, revitalization of the old cultural, historical and religious heritage, etc. Projects that have improved the infrastructure related to the tourist signs were implemented. As a result, today, tourists are better informed about the tourist attractions in Skopje. As well, a new pedestrian and biking path along the Vardar River was built.

The transformation of the urban space and the increased tourist offer affected the tourist demand. The organization of numerous conferences, congresses, cultural and other events improved the ratings of Skopje, and the city gained the image of an open and fast-growing destination (Figure 5). However, Skopje will have to compete with other cities to attract tourists, especially with cities in Southeast Europe. According to the 'Tourism Strategy with Action Plan of the City of Skopje for the period 20142018', the lack of adequate promotion can reduce the competitiveness of Skopje compared to other cities in Southeast Europe.

Foreign tourists accounted for $90.5 \%$ of the total number of tourists in 2016. The international tourist market has become strongly segmented (Table 1). The share of tourists from the countries of Southeast Europe (Serbia, Montenegro, Greece, Croatia, Bulgaria, Slovenia, Albania, Bosnia and Herzegovina, Romania and Kosovo) decreased from $50.6 \%$ (2005) to $32.3 \%$ (2016). In contrast, there is an increase in the number of foreign tourists with greater purchasing power from countries such as Germany, Italy, the United Kingdom, France, Austria, the Netherlands, Sweden, Poland and the United States (Table 1).

The results of the calculation of the index of effectiveness (Ef) indicate that tourists from the United States, Germany, Italy, and the United Kingdom differ from tourists coming from the countries of Southeast Europe, especially from countries such as Albania, Montenegro and Kosovo, which are not ranked in the top 20 countries according to this criterion (Figure 6). The index of effectiveness shows different levels of purchasing power of foreign tourists: Turkey (566), USA (536), Germany (471), Italy (369), UK (355), Croatia (305), Netherlands (299), Austria (290), Bulgaria 


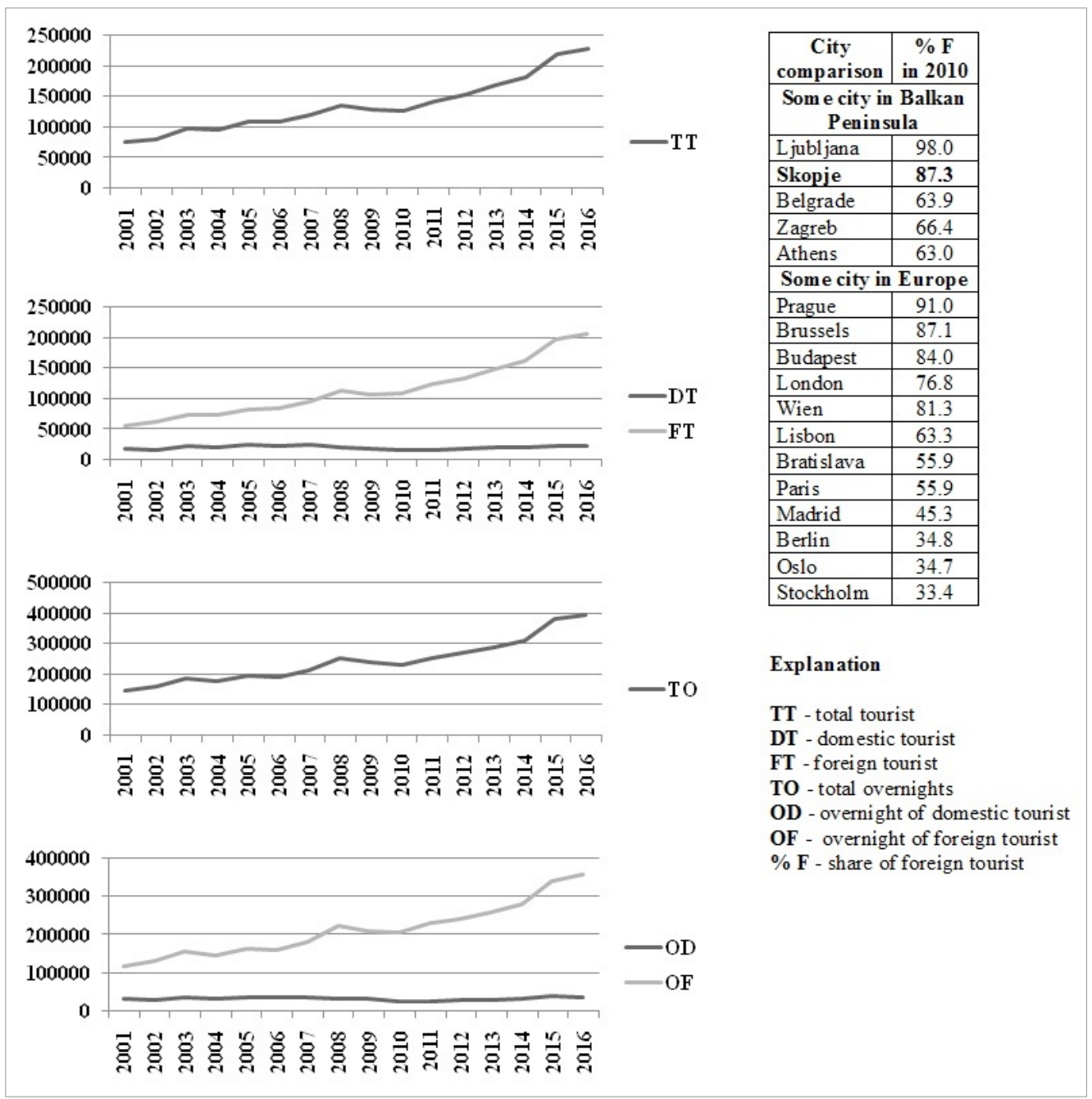

Figure 5: Key performance indicators of tourist flows in Skopje (2001-2016)

Source: Own calculations based on data from the State Statistical Office and Eurostat Database

(266), Slovenia (261), Serbia (261), Switzerland (258), Norway (255), Greece (247), France (241), Belgium (238), Denmark (218), Sweden (218), Romania (199) and Poland (191) (Figure 6).

The highest value of the index of effectiveness was calculated for Turkish tourists. It is a result of the large number of Turkish tourists who visited Skopje. The value of PPs for Turkish tourists is less than the value of tourists coming from the USA, Germany, Italy, the United Kingdom, the Netherlands, etc. (Table 1). However, Turkish tourists are a very important market segment for the City of Skopje. In general, the index indicates differences in the available income among international tourists from the selected countries. 
Table 1: International tourists in Skopje (top 20 countries).

\begin{tabular}{lrcc}
\hline \multirow{2}{*}{ Country } & \multicolumn{3}{c}{$\mathbf{2 0 0 5}$} \\
\cline { 2 - 4 } & $\mathrm{F}$ & AOs & PPs \\
\hline Serbia and M. & 13,307 & 1.5 & 31 \\
Greece & 4,678 & 1.7 & 93 \\
Croatia & 4,571 & 1.7 & 55 \\
USA & 4,284 & 2.7 & 160 \\
Bulgaria & 4,270 & 1.9 & 37 \\
\hline Germany & 3,669 & 2.1 & 117 \\
Slovenia & 3,517 & 2.0 & 87 \\
Turkey & 3,245 & 2.1 & 43 \\
Albania & 3,025 & 1.5 & 21 \\
UK & 2,838 & 2.6 & 118 \\
Italy & 2,402 & 2.0 & 109 \\
Bosnia and H. & 1,615 & 1.8 & 25 \\
\hline Austria & 1,452 & 1.9 & 127 \\
France & 1,409 & 2.1 & 111 \\
Netherlands & 1,321 & 2.7 & 135 \\
Hungary & 1,057 & 1.8 & 62 \\
\hline Romania & 874 & 2.2 & 35 \\
\hline Czech Republic & 816 & 2.5 & 79 \\
\hline Switzerland & 778 & 2.1 & 146 \\
Russian F. & 748 & 2.3 & $\mathrm{n} / \mathrm{a}$ \\
\hline
\end{tabular}

\begin{tabular}{lrcc}
\hline \multirow{2}{*}{ Country } & \multicolumn{3}{c}{$\mathbf{2 0 1 6}$} \\
\cline { 2 - 4 } & $\mathrm{F}$ & AOs & PPs \\
\hline Turkey & 45,058 & 1.4 & 64 \\
Serbia & 16,575 & 1.7 & 37 \\
Bulgaria & 8,676 & 1.5 & 49 \\
Germany & 8,119 & 2.0 & 123 \\
Croatia & 7,776 & 1.8 & 60 \\
Italy & 6,674 & 1.9 & 97 \\
USA & 6,625 & 2.7 & 145 \\
Albania & 5,081 & 1.4 & 29 \\
China & 4,926 & 1.5 & $\mathrm{n} / \mathrm{a}$ \\
UK & 4,814 & 2.2 & 107 \\
Greece & 4,749 & 1.7 & 68 \\
Slovenia & 4,106 & 1.8 & 83 \\
Kosovo & 3,957 & 1.5 & $\mathrm{n} / \mathrm{a}$ \\
Romania & 3,628 & 1.7 & 58 \\
Sweden & 3,490 & 2.1 & 123 \\
Austria & 3,489 & 1.7 & 128 \\
\hline Netherlands & 2,867 & 2.2 & 128 \\
\hline France & 2,793 & 1.8 & 104 \\
\hline Bosnia and H. & 2,776 & 2.0 & 32 \\
\hline Poland & 2,410 & 2.0 & 68 \\
\hline
\end{tabular}

Note: $\mathrm{F}$ - foreign tourists; AOs - average number of overnights of foreign tourists; GDP per capita in PPs for 2005 (Index EU-28 countries: 100; Euro area-19 countries: 110) and for 2016 (Index EU-28 countries: 100; Euro area-19 countries: 106).

Source: Own calculations based on data from the State Statistical Office and European Commission - Eurostat Database



Figure 6: Ef index of foreign tourists in Skopje, top 20 countries, in 2016

Source: Own calculations based on data from the State Statistical Office (MakStat database) and European Commission - Eurostat Database 
At the same time, the competitiveness and sustainability of the tourism business impose the need to build accommodation facilities that have a growth tendency. During the analyzed period (2001-2016), the number of accommodation facilities increased. In general, the accommodation infrastructure in the city has been improved and expanded and a new geography of supply and demand has been generated. In 2001, there were 41 accommodation facilities, of which 23 were hotels (SSORM). In 2016, the number of accommodation facilities increased to 120 , which were dispersed in different municipalities: Aerodrom (3), Butel (2), Gazi Baba (2), Karposh (23), Kisela Voda (7), Saraj (1), Centar (69) and Chair (13) (SSORM, 2017). Of the 120 accommodation facilities, 82 were hotels (SSORM). As well, new hotels were built outside the city center, i.e. in the surrounding municipalities such as: Karposh, Kisela Voda, Aerodrom, etc. The reasons for the dispersion of hotels and other accommodation facilities in the surrounding municipalities are lower land prices and good transport connectivity. In 2016, Skopje had a diverse hotel offer: 11 (5-star hotels), 25 (4-star hotels), 23 (3-star hotels), 9 (2-star hotels) and 14 (1-star hotels) (SSORM). The dispersion and construction of service facilities that do not endanger the space in the City of Skopje also affect the development of complementary activities (MEPP, 2010).



Figure 7: Spatial distribution of commercial accommodation capacities and application of the Bo method

Source: Map made by the author based on data from the State Statistical Office

The results obtained with the Bo method indicate changes in the utilization of accommodation capacities in Skopje (Figure 7). The utilization of accommodation capacities in Skopje increased from 5.75\% in 2001 to $10.21 \%$ in 2016. These changes occurred as a result of several factors, such as: more effective management of hotels and 
other accommodation facilities and their adaptation to the market; increasing the level of service quality; specialization and competitiveness, etc. The dispersion of the hotel business and other accommodation facilities outside the city center and new business challenges have increased the potential for the development of business tourism. The development of business tourism is of great importance, or as Coles (2003) says 'business tourism should yield notable returns because such tourists spend more per capita on hospitality and accommodation than private visitors' (p. 209).

\subsection{A new paradigm of urban regeneration or a well-known practice in the European context?}

In the last three decades, tourism and urban regeneration in Europe have become closely linked through the concept of cultural regeneration (Kennell, 2013). Using culture as a tool for urban regeneration has been a well-known practice in Europe for a long time. The use of culture as a key tool for urban regeneration in Western Europe was a consequence to the economic decline of industrial production in cities, as well as growing inter-city competition. Many cities/urban destinations in Europe use culture and cultural resources to attract visitors and investors. Cities such as Glasgow, Bilbao and Barcelona, have become models showing how a city can attract more tourists through urban regeneration strategies. Many cities have recognized the significance of culture and developed different strategies and models to incorporate culture into urban regeneration (e.g. European Capital of Culture, heritage preservation, festivals and mega-events, cultural quarters - museums, galleries, conference centers, theaters, etc.).

Examples of urban regeneration and transformation can also be seen in the countries of the former Yugoslavia and other post-socialist countries (see Kesar, Deželjin and Bienenfeld, 2015; Lazarević, Koružnjak and Devetaković, 2016; Pobric and Robinson, 2019; Pojani, 2010). Cities have a different structure, culture and identity, so it is impossible to make a perfect and universal model of urban regeneration. The question arises: if the context in Skopje is different or, on the contrary, similar to Southeast Europe and/or the rest of Europe in terms of challenges regarding tourism/culture-led urban regeneration? Unlike some European cities that experienced a decline in the city center, where buildings remained empty, derelict and ended up collapsing (see Balsas, 2004) and later were regenerated, the city center of Skopje was rebuilt in a different way. The project for reconstruction of the central core of the city implemented under the umbrella of 'Skopje 2014' can be described as belonging to the 'hard' cultural infrastructure and physical solutions of urban redevelopment, i.e. physical interventions in the public space and construction of permanent and highly visible cultural buildings and structures, fundamentally designed as prestige devices, intended to boosting the city image and national identity, as well as attract tourists. According to Grcheva (2019), the essence of the new doctrine is architectural and was so embedded in the planning system, so it continued to expand its borders outside the city 
center, which has led to similar facades of some ministry and residential buildings, commercial buildings, and a couple of parking garages.

The 'Skopje 2014' project is a politically driven and managed project. Due to its coherent manifestation and wide impact, it can be considered as a newly formed planning doctrine and urban renewal (Grcheva, 2019). The 'Skopje 2014' project is a result of the complex relationship between national politics, state ideologies and urban planning. Although the reconstructed and new buildings (baroque and neoclassical architecture), which were branded under the common banner 'Skopje 2014', caused controversies and serious criticism from the experts and architectural community, the government did not abandon its plans (Bouzarovski, 2011), and the nationalistic planning doctrine (see Grcheva, 2019), which is strongly related to the concepts of homeland and ethnicity (see Yiftachel, 2006), and based on a powerful political ideology that develops around the concept of nationalism (Grcheva, 2019).

In general, the renewal/regeneration of specific central spaces of Skopje for a great majority of scholars is exaggerated and controversial, not following 'organic' urban development and European trends. Nevertheless, Skopje has catalyzed a new example of urban regeneration driven by culture and tourism in Southeast Europe. Creating the city's 'cosmopolitan identity' has led to the creation of a seemingly authentic urban space that is attractive to tourists, but still lacks an original relationship with the concrete place. Foreign tourists, and even some residents, are often unaware of the symbolic buildings/monuments, considering them as a form of Macedonian post-modernism, authentic cultural experience and expression of ethno-cultural consumption.

\section{Discussion and conclusion}

The current paper reinforces the theory of tourism-led urban regeneration (Karski, 1990; Law, 1991, 1992, 2000; Martin and Mason, 1988; Swarbrooke, 2000), improves the current understanding of culture-led urban regeneration, and proposes a new and integrated conceptual framework for exploring these processes. The examples in the literature (see Coles, 2003; Couch and Farr, 2000; Joksimović et al., 2014; Rátz et al., 2008; Stevenson, 2013) indicate that there is no single model of tourism-led urban regeneration, and that it depends from the characteristics of the city (urban morphology, geographical context, level of cultural, economic and tourism development, etc.). The study framework proposes four sub-dimensions that are important in the process of urban regeneration: culture-led regeneration; tourist attractions (traditional, new and regenerated) and their spatial distribution; restoring foreign tourist flows; and redistribution of the hotel business and accommodation establishments. The question that arises here is: What's the amount of the conceptual framework generalized value? The conceptual model can be used as a framework for future empirical research in different cities and different socio-cultural contexts. The conceptual framework also expands the knowledge and understanding of Law's (2000) conventional model. 
The study suggests that both sub-dimensions: culture-led regeneration and redistribution of the hotel business and accommodation establishments should be 'physically' added to the Law's (2000) model of tourism and urban regeneration to emphasize their significant, distinctive and versatile role in the urban regeneration process.

The City of Skopje, an iconic urban tourism place in North Macedonia, was the focus of this paper. Skopje is a new example of urban regeneration driven by tourism and the 'Skopje 2014' project in Southeast Europe. The 'Skopje 2014' project contributed to a wide screening of new post-socialist images of the city, as well as an increase in the number of foreign tourists. Foreign tourists are most concentrated in the central core of the city, where most of the monuments and buildings from the 'Skopje 2014' project and most of the services are located. In 2016, foreign tourists in the Municipality of Centar accounted for $53.1 \%$ of the total number of foreign tourists. The findings showed that the image and identity of the city core, as well as the tourist flows in Skopje have changed radically in a short period of time.

The current study also contributed to a better understanding of the relationships between tourist attractions, tourism development and city regeneration. The new tourist attractions that were built outside the city center, revitalized the space and encouraged the development of tourism in other urban municipalities. The findings of the current study are in line with previous studies (Joksimović et al., 2014; Rátz et al., 2008), which have demonstrated that tourist attractions affect city regeneration.

The previous discussion showed that in recent years the character of the city has significantly changed and that tourism is becoming the major theme. The findings indicate that the number of foreign tourists is constantly increasing. The number of foreign tourists has increased in other urban municipalities, such as Chair, Aerodrom and Kisela Voda. These findings support previous assumptions in the Maitland (2007b) study, which suggest that more experienced visitors to large cities may want to move away from traditional tourist beats. In essence, the current study found that the city's regeneration, new tourist attractions, and general tourism development influenced the increase in foreign visitors.

The current study also explored the relationships between redistribution of hotels/accommodation facilities, tourism development and city regeneration. The results indicate changes in the geography of hotels/accommodation facilities and their increased utilization in recent years. The model of distribution of hotels/accommodation facilities in Skopje indicates certain similarities with the models of urban hotel distribution proposed by Ritter (1986) and Ashworth (1989). Initially, hotels/accommodation establishments occupied central locations, and later started to disperse from the central city core toward the periphery municipalities. The accessibility and good transport connection to the city center, land price, etc., are factors that influenced these transformational processes. In general, the spatial distribution of the hotel business and accommodation facilities affected the tourism development, as well as the economic and physical regeneration of the city. 
From the findings of the current paper can be drawn a set of lessons learned that can be useful for policymakers in North Macedonia and the region as a whole. The 'Skopje 2014' case was an attempt 'to offer a perspective on one shade of planning theory from the South-East, specifically one coming from a post-socialist Balkan context' or 'a planning doctrine shaped by nationalism, a concept rarely discussed in mainstream planning theory (...)' (Grcheva, 2019, p. 153). On the other hand, the literature shows that 'nationalist aspirations have emerged as dominant factors shaping the urban landscape in post-socialist cities (Andrusz, Harloe and Szelenyi, 2011; Diener and Hagen, 2015; quoted in Grcheva, 2019, p. 153). However, some scholars, regarding the 'Skopje 2014' case, remain cautious and emphasize that the concept of nationalism should not be immediately generalized as one of features of planning theory from the South East (Grcheva, 2019), which should serve as a planning practice.

The 'Skopje 2014' project is a major public investment in cultural buildings and other urban structures. In view of the fact that many cities have limited public investment, it is clear that this example of urban renewal/regeneration is difficult to follow everywhere in the region. With the 'Skopje 2014' project, great emphasis was put on public investments and the physical renewal/regeneration of public space, which was done at the expense of building and strengthening civic creativity. Authorities need to be more ambitious and more democratically oriented in their approach. Instead of encouraging a 'top-down' approach, emphasis should be put on providing a platform for local communities (including the average citizen) and specialized agencies to express their views and expectations and examine the decision-making process. Therefore, the authorities should consider a model of 'bottom-up' activism in the city's regeneration and unite people from the local community to promote a positive sense of place. In this way the feeling of alienation, misrepresentation and lack of ownership can be avoided.

Policymakers should be aware that the goals of urban regeneration strategies can also be achieved without huge levels of public investment. These strategies should include festivals celebrating local creativity, music and dance shows, art, theater, concerts, exhibitions, local cuisine (food and drink), workshops, etc. Regeneration that is driven by cultural producers/production creates new resources for cultural tourism. Therefore, it is necessary to encourage initiatives for the development of cultural products through networking and partnership of the cultural and tourism sector. In essence, for cultural tourism to continue to influence urban regeneration, cultural policymakers as well as tourism and regeneration professionals need to develop new ways of working and partnership with cultural producers and the local community. Without these relationships the main driver of regeneration can be lost. This approach should improve the quality of life, creativity, tourism and the sense of place.

The authorities can use the results of the current study for a variety of purposes: to identify, develop and promote both the old and the new tourist sites and attractions that were presented here; to identify target groups from the foreign tourism market; to better understand and manage foreign tourist movements and consumption; to 
better understand the spatial dispersion and utilization of accommodation facilities, especially in the new challenges of attracting new investments from multiple international hotel chains and their positioning in strategic locations in urban municipalities. The authorities should also enable synergies between all stakeholders and initiate/implement projects capable of demonstrating good practices and inducing 'civic creativity' in the retail, hotel and restaurant industries. Creativity and innovation can foster urban development, social cohesion and human progress. Indeed, investing in tourism can lead to sustainable practices if the process is embedded within a consistent approach to tourism policy.

\section{Limitations and directions for future research}

Some limitations of the current study give potential directions for further research. The lack of detailed statistical data was a limiting factor for a deeper analysis of the relationship between tourism and urban regeneration. Maitland (2007b) says that 'evidence is hard to come by; there are generally no regularly collected, consistent and reliable data on tourism activity at the local level in major cities' (p. 28). In this context, it should be emphasized that the State Statistical Office does not provide detailed statistical data on tourism activities in Skopje. It was also difficult to obtain detailed and reliable financial data for the 'Skopje 2014' project. Hence, the current study uses only available geographic and statistical data to explain phenomena and processes. Future research should focus on analyzes based on surveys or in-depth interviews with public sector authorities responsible for tourism and culture, tourism/culture suppliers, foreign tourists, locals, etc. Such analyzes can improve our understanding of urban regeneration driven by tourism and culture.

At a broader conceptual level, the following critical issues are worthy of future research: What are the new governance challenges related to tourism/culture-led urban regeneration strategies? What is the role of the public sector authorities, the private sector and the local community in creating these strategies and in the decision-making process? What are the problems faced by all stakeholders in these challenges, and how can these be resolved? Furthermore, comparative case studies between Southeast European cities can help to identify appropriate strategies for overcoming tourism/culture-led regeneration dilemmas.

\section{References:}

1. Andrusz, G., Harloe, M. and Szelenyi., I., Cities after Socialism: Urban and Regional Change and Conflict in Post-socialist Societies, Hoboken, NJ: John Wiley \& Sons, 2011.

2. Ashworth, G.J., 'Accommodation and the Historic City', 1989, Built Environment, vol. 15, no. 2, pp. 92-100.

3. Balkan Investigative Reporting Network, 'Skopje 2014 Uncovered', [Online] available at http://skopje2014.prizma.birn.eu.com/en, accessed on November 17, 2016.

4. Balsas, C.J.L., 'City Centre Regeneration in the Context of the 2001 European Capital of Culture in Porto, Portugal', 2004, Local Economy, vol. 19, no. 4, pp. 396-410. 
5. Bouzarovski, S., 'Skopje', 2011, Cities, vol. 28, no. 3, pp. 265-277.

6. Chancellor, C. and Cole, S., 'Using Geographic Information System to Visualize Travel Patterns and Market Research Data', 2008, fournal of Travel \& Tourism Marketing, vol. 25, no. 3-4, pp. 341-354.

7. Coles, T., 'Urban Tourism, Place Promotion and Economic Restructuring: The Case of Post-socialist Leipzig', 2003, Tourism Geographies: An International fournal of Tourism Space, Place and Environment, vol. 5, no. 2, pp. 190-219.

8. Couch, C. and Farr, S.J., 'Museums, Galleries, Tourism and Regeneration: Some Experiences from Liverpool', 2000, Built Environment, vol. 26, no. 2, pp. 152-163.

9. Diener, A.C. and Hagen, J. (eds.), From Socialist to Post-socialist Cities: Cultural Politics of Architecture, Urban Planning, and Identity in Eurasia, Abingdon: Routledge, 2015.

10. Dimova, R., 'Elusive Centres of a Balkan City: Skopje between Undesirable and Reluctant Heritage', 2019, International fournal of Heritage Studies, vol. 25, no. 9, pp. 958-973.

11. Donevska, N., 'Trade-offs in Sustainable Urban Development: The Case of Skopje', 2017, Fournal of Environmental Studies and Sciences, vol. 7, pp. 152-159.

12. Dye, A.S. and Shaw, S.L., 'A GIS-based Spatial Decision Support System for Tourists of Great Smoky Mountains National Park', 2007, Journal of Retailing and Consumer Services, vol. 14 , no. 4 , pp. 269-278.

13. Edwards, D., Griffin, T. and Hayllar, B., 'Urban Tourism Research: Developing an Agenda', 2008, Annals of Tourism Research, vol. 35, no. 4, pp. 1032-1052.

14. European Commission, Eurostat Database, [Online] available at http://ec.europa.eu/ eurostat $/ \mathrm{tgm} /$ table.do?tab=table \&init=1\&language=en \&pcode=tec $00114 \&$ plugin $=1$, accessed on December 1, 2017.

15. Evans, G., 'Hard-branding the Cultural City - From Prado to Prada', 2003, International Journal of Urban and Regional Research, vol. 27, no. 2, pp. 417-440.

16. Evans, G., 'The Contribution of Culture to Regeneration in the UK: A Review of the Evidence', in Proceedings of $3^{\text {rd }}$ International Conference on Cultural Policy Research in Montreal, Canada, August 2004.

17. Evans, G., 'Measure for Measure: Evaluating the Evidence of Culture's Contribution to Regeneration', 2005, Urban Studies, vol. 42, no. 5-6, pp. 959-983.

18. Florida, R., The Rise of the Creative Class, New York: Basic Books, 2002.

19. Galdini, R., 'Tourism and the City: Opportunity for Regeneration', 2007, Tourismos: An International Multidisciplinary fournal of Tourism, vol. 2, no. 2, pp. 95-111.

20. Grcheva, L., 'The Birth of a Nationalistic Planning Doctrine: The 'Skopje 2014' Project', 2019, International Planning Studies, vol. 24, no. 2, pp. 140-155.

21. Joksimović, M., Golić, R., Vujadinović, S., Šabić, D., Jovanović Popović, D. and Barnfield, G., 'Restoring Tourist Flows and Regenerating City's Image: The Case of Belgrade', 2014, Current Issues in Tourism, vol. 17, no. 3, pp. 220-233.

22. Karski, A., 'Urban Tourism: A Key to Urban Regeneration?', 1990, The Planner, vol. 76, no. 13, pp. 15-17.

23. Kennell, J., 'After the Crisis: Cultural Tourism and Urban Regeneration in Europe', in Smith, M. and Richards, G. (eds.), The Routledge Handbook of Cultural Tourism, Abingdon: Routledge, 2013, pp. 317-323. 
24. Kesar, O., Deželjin, R. and Bienenfeld, M., 'Tourism Gentrification in the City of Zagreb: Time for a Debate?', 2015, Interdisciplinary Management Research, vol. 11, pp. 657-668.

25. Lau, G. and McKercher, B., 'Understanding Tourist Movement Patterns in a Destination: A GIS Approach', 2006, Tourism and Hospitality Research, vol. 7, no. 1, pp. 39-49.

26. Law, C.M., 'Tourism and Urban Revitalization', 1991, East Midlands Geographer, vol. 14, no. $1 / 2$, pp. $49-60$.

27. Law, C.M., 'Urban Tourism and its Contribution to Economic Regeneration', 1992, Urban Studies, vol. 29, no. 3/4, pp. 599-618.

28. Law, C.M., Urban Tourism: Attracting Visitors to Large Cities, London: Mansell Publishing, 1993.

29. Law, C.M., Tourism in Major Cities, London: International Thompson Business Press/ Routledge, 1996.

30. Law, C.M., 'Regenerating the City Centre through Leisure and Tourism', 2000, Built Environment, vol. 26, no. 2, pp. 117-129.

31. Law, C.M., Urban Tourism: The Visitor Economy and the Growth of Large Cities, London: Continuum, 2002.

32. Lazarević, E.V., Koružnjak, A.B. and Devetaković, M., 'Culture Design-led Regeneration as a Tool Used to Regenerate Deprived Areas. Belgrade - The Savamala Quarter; Reflections on an Unplanned Cultural Zone', 2016, Energy and Buildings, vol. 115, pp. 3-10.

33. Maitland, R. and Newman, P., 'Developing Metropolitan Tourism on the Fringe of Central London', 2004, International fournal of Tourism Research, vol. 6, no. 5, pp. 339-348.

34. Maitland, R., 'Tourism, the Creative Class and Distinctive Areas in Major Cities: The Roles of Visitors and Residents in Developing New Tourism Areas', in Richards, G. and Wilson, J. (eds.), Tourism, Creativity and Development, London: Routledge, 2007a, pp. 73-86.

35. Maitland, R., 'Culture, City Users and the Creation of New Tourism Areas in Cities', in Smith, M.K. (ed.), Tourism, Culture and Regeneration, Cambridge: CABI Publishing, 2007b, pp. 25-34.

36. Martin, B. and Mason, S., 'The Role of Tourism in Urban Regeneration', 1988, Leisure Studies, vol. 7, no. 1, pp. 75-80.

37. Miles, S. and Paddison, R., 'Introduction: The Rise and Rise of Culture-led Urban Regeneration', 2005, Urban Studies, vol. 42, no. 5-6, pp. 833-839.

38. Ministry of Environment and Physical Planning [MEPP], 'Spatial Plan of the Skopje Region 2005 - 2020, Draft', Skopje, 2010.

39. Mommaas, H., 'Cultural Clusters and the Post-industrial City: Towards the Remapping of Urban Cultural Policy', 2004, Urban Studies, vol. 41, no. 3, pp. 507-532.

40. Norris, D.F., 'If We Build It, They Will Come! Tourism-based Economic Development in Baltimore', in Judd, D.R. (ed.), The Infrastructure of Play: Building the Tourist City, New York: M.E. Sharpe, 2003, pp. 125-167.

41. Pobric, A. and Robinson, G.M., 'Recent Urban Development and Gentrification in PostDayton Sarajevo, Bosnia and Herzegovina', 2019, Cities, vol. 89, pp. 281-295.

42. Pojani, D., 'Tirana', 2010, Cities, vol. 27, no. 6, pp. 483-495.

43. Puczko, L., Ratz, T. and Smith, M., 'Old City, New Image: Perception, Positioning and Promotion of Budapest', 2007, Journal of Travel \& Tourism Marketing, vol. 22, no. 3-4, pp. 21-34. 
44. Rátz, T., Smith, M. and Michalkó, G., 'New Places in Old Spaces: Mapping Tourism and Regeneration in Budapest', 2008, Tourism Geographies: An International Journal of Tourism Space, Place and Environment, vol. 10, no. 4, pp. 429-451.

45. Richards, G. and Wilson, J., 'The Creative Turn in Regeneration: Creative Spaces, Spectacles and Tourism in Cities', in Smith, M.K. (ed.), Tourism, Culture and Regeneration, Cambridge: CAB International, 2007, pp. 12-24.

46. Richards, G., 'Creativity and Tourism in the City', 2014, Current Issues in Tourism, vol. 17, no. 2, pp. 119-144.

47. Ritter, W., 'Hotel Location in Big Cities', in Vetter, F. (ed.), Big City Tourism, Berlin: Reimer, 1986, pp. 355-364.

48. Sarrión-Gavilán, M.D., Benítez-Márquez, M.D. and Mora-Rangel, E.O., 'Spatial Distribution of Tourism Supply in Andalusia', 2015, Tourism Management Perspectives, vol. 15, pp. 29-45.

49. Sasaki, M., 'Urban Regeneration through Cultural Creativity and Social Inclusion: Rethinking Creative City Theory through a Japanese Case Study', 2010, Cities, vol. 27, Supplement 1, pp. S3-S9.

50. Smith, M.K., 'Towards a Cultural Planning Approach to Regeneration', in Smith, M.K. (ed.), Tourism, Culture and Regeneration, Cambridge: CABI Publishing, 2007, pp. 1-11.

51. State Statistical Office of the Republic of Macedonia [SSORM], 'Census of Catering Capacities in the Republic of Macedonia, 2016. Statistical Reviews: Transport, Tourism and Other Services', Skopje: State Statistical Office of the Republic of Macedonia, 2017.

52. State Statistical Office of the Republic of Macedonia [SSORM], 'Regions of the Republic of Macedonia, 2018', Skopje: State Statistical Office of the Republic of Macedonia, 2018.

53. State Statistical Office of the Republic of Macedonia, MakStat database, [Online] available at http://makstat.stat.gov.mk/PXWeb/pxweb/en/MakStat/?rxid=46ee0f64-2992-4b45-a2d9cb4e5f7ec5ef, accessed on June 20, 2018.

54. Stevenson, N., 'The Complexities of Tourism and Regeneration: The Case of the 2012 Olympic Games', 2013, Tourism Planning \& Development, vol. 10, no. 1, pp. 1-16.

55. Swarbrooke, J., 'Tourism, Economic Development and Urban Regeneration: A Critical Evaluation', in Robinson, M., Sharpley, R., Evans, N., Long, P. and Swarbrooke, J. (eds.), Developments in Urban and Rural Tourism: Reflections on International Tourism, Sunderland: Business Education Press, 2000, pp. 269-285.

56. Target Communications, 'Tourism Strategy with Action Plan of the City of Skopje for the period 2014-2018', Skopje, 2014.

57. Yang, Y. and Wong, K.K.F., 'Spatial Distribution of Tourist Flows to China's Cities', 2013, Tourism Geographies: An International Journal of Tourism Space, Place and Environment, vol. 15, no. 2, pp. 338-363.

58. Yiftachel, O., 'Re-engaging Planning Theory? Towards 'South-Eastern' Perspectives', 2006, Planning Theory, vol. 5, no. 3, pp. 211-222. 